\title{
Cardiorespiratory and hemogasometric effects of epidural ketamine and its associations with morphine and xylazine in sheep
}

\section{Efeitos cardiorrespiratórios e hemogasométricos da cetamina e suas associações com morfina e xilazina por via epidural em ovinos}

Ceci Ribeiro Leite ${ }^{1 *}$; Fabio Otero Ascoli2; Juliana de Oliveira ${ }^{2}$; Daniel Andrews de Moura Fernandes ${ }^{3}$; Jeferson Ferreira da Fonseca ${ }^{4}$; Felipe Zandonadi Brandão²

Highlights

Epidural ketamine-xylazine promoted slight hypoxemia in sheep.

Epidural ketamine-morphine decreased body temperature in sheep.

Epidural ketamine alone showed cardiorespiratory stability in sheep.

\begin{abstract}
This study aimed to evaluate the cardiorespiratory and hemogasometric effects of epidural ketamine and its associations with morphine and xylazine, in ewes subjected to cervix transposition with a Hegar dilator. Ten Santa Inês ewes were studied in a crossover model study where three epidural protocols $\left(G_{K}=\right.$ ketamine $2.0 \mathrm{mg} \mathrm{kg}^{-1}, \mathrm{G}_{\mathrm{KM}}=$ ketamine $2.0 \mathrm{mg} \mathrm{kg}^{-1}+$ morphine $0.1 \mathrm{mg} \mathrm{kg}^{-1}$, and $\mathrm{G}_{\mathrm{KX}}=$ ketamine $2.0 \mathrm{mg} \mathrm{kg}^{-1}$ + xylazine $\left.0.05 \mathrm{mg} \mathrm{kg}^{-1}\right)$ were compared with each other and with a control treatment $\left(\mathrm{G}_{\mathrm{S}}=\right.$ saline $1 \mathrm{~mL} / 7.5$ $\mathrm{kg}$ ). The assessed variables were heart rate, respiratory rate, ear temperature, noninvasive blood pressure, and blood gas parameters. All parameters were assessed at baseline before the ewes were sedated with a combination of acepromazine $\left(0.1 \mathrm{mg} \mathrm{kg}^{-1}\right)$ and diazepam $\left(0.2 \mathrm{mg} \mathrm{kg}^{-1}\right)$. Ten minutes after sedation, all parameters were reassessed and epidural injections were performed. Blood gas analysis was repeated 15 and 30 min after epidural administration, and the other parameters were assessed at 5, 15, 30, 45, and 60 min after epidural administration. The $\mathrm{G}_{\mathrm{kx}}$ ewes showed signs of hypoxemia with lower levels of $\mathrm{pO}_{2}$ and a compensatory increase in respiratory rate. The $G_{K M}$ ewes presented a lower mean temperature. There were few cardiorespiratory effects in any of the protocols compared with that of the control. The epidural

1 Dra, MV. Servidora, Universidade Federal Fluminense, UFF, Niterói, RJ, Brasil. E-mail: ceci_ribeiro@id.uff.br

2 Profs. Drs., Curso de Graduação em Medicina Veterinária, UFF, Niterói, RJ, Brasil. E-mail: fabioascoli@id.uff.br; juoliveira@id.uff.br; fzbrandao@id.uff.br

${ }^{3}$ Discente do Curso de Mestrado do Programa de Pós-Graduação em Medicina Veterinária, Clínica e Reprodução Animal, UFF, Niterói, RJ, Brasil. E-mail: daniel_andrews_2@yahoo.com.br

${ }^{4}$ Dr. Pesquisador, Empresa Brasileira de Pesquisa Agropecuária, EMBRAPA, Coronel Pacheco, MG, Brasil. E-mail: jeferson.fonseca@embrapa.br

* Author for correspondence
\end{abstract}

Received: May 12, 2020 - Approved: Oct. 14, 2020 
with $2.0 \mathrm{mg} \mathrm{kg}^{-1}$ ketamine alone was considered the more suitable option for short procedures, such as obstetric manipulations, in sheep because of its cardiorespiratory stability when compared with that when combination drugs were used.

Key words: Analgesia. Loco-regional anesthesia. Acid-base balance.

\section{Resumo}

Este estudo teve como objetivo avaliar os efeitos cardiorrespiratórios e hemogasométricos da cetamina peridural e suas associações com morfina e xilazina em ovelhas submetidas à manipulação uterina por via transcervical. Foram estudadas dez ovelhas da raça Santa Inês. Três protocolos epidurais foram avaliados: $\left(\mathrm{G}_{\mathrm{K}}=\right.$ cetamina $2,0 \mathrm{mg} \mathrm{kg}-1, \mathrm{G}_{\mathrm{KM}}=$ cetamina $2,0 \mathrm{mg} \mathrm{kg}^{-1}+$ morfina $0,1 \mathrm{mg} \mathrm{kg}^{-1}, \mathrm{G}_{\mathrm{Kx}}=$ cetamina 2,0 $\mathrm{mg} \mathrm{kg}^{-1}+$ xilazina $0,05 \mathrm{mg} \mathrm{kg}^{-1}$ ). Os três protocolos foram comparados entre si e com um tratamento controle $\left(G_{\mathrm{s}}=\right.$ solução salina $\left.1 \mathrm{~mL} / 7,5 \mathrm{~kg}\right)$. As variáveis avaliadas foram frequência cardíaca, frequência respiratória, temperatura auricular, pressão arterial não-invasiva além da análise hemogasométrica. Todos os parâmetros foram avaliados no momento basal e em seguida as ovelhas foram sedadas com associação de acepromazina $\left(0,1 \mathrm{mg} \mathrm{kg}^{-1}\right)$ e diazepam $\left(0,2 \mathrm{mg} \mathrm{kg}^{-1}\right)$. Dez minutos após a sedação, todos os parâmetros foram novamente avaliados e foram realizadas as injeções peridurais. A hemogasometria foi repetida aos 15 e 30 minutos após a peridural e os outros parâmetros avaliados aos 05, 15, 30, 45, e 60 minutos após a peridural. $\mathrm{O}_{\mathrm{kx}}$ mostrou sinais de hipoxemia com menores níveis de $\mathrm{pO}_{2}$ e um aumento compensatório na frequência respiratória. $O G_{K M}$ apresentou a média de temperatura mais baixa. Todos os protocolos apresentaram poucos efeitos cardiorrespiratórios em relação ao controle. O protocolo epidural com 2,0 $\mathrm{mg} \mathrm{kg}^{-1}$ de cetamina foi considerado a melhor opção para procedimentos curtos como manipulações obstétricas em ovinos devido à estabilidade cardiorrespiratória quando comparado com os protocolos que utilizaram associações.

Palavras-chave: Analgesia. Anestesia loco-regional. Equilíbrio ácido-base.

\section{Introduction}

Epidural anesthesia is a technique used in small ruminants for various procedures where desensitization of the pelvic limbs, tail, perineum, rectum, vulva, or vagina is required. Reproductive procedures, such as artificial insemination or embryo transfer, require analgesia and relaxation of the vulva and vagina and epidural anesthesia can provide adequate desensitization of these structures. The most commonly used drugs are local anesthetics that promote nonselective blockade of both sensitive and motor fibers (DeRossi et al., 2012). The most undesired consequence of such motor blockade is recumbence when a standing position is needed. Other drugs, such as $\alpha_{2-}$ agonists, dissociative agents, and opioids, have been used in various species for their analgesic properties (Guirro, Sobrinho, Ferreira, \& Valadão, 2011; Habibian, Bigham, \& Aali, 2011), minimizing or avoiding recumbency and promoting analgesia and relaxation. Ketamine is a dissociative agent that acts as an $\mathrm{N}$-methyl-D-aspartate receptor antagonist. These receptors are directly involved in the transmission and modulation of nociceptive information at the medulla level, and some studies have used epidural ketamine to reduce the transmission of nociceptive stimuli and 
promote analgesia (Ismail, 2016). Xylazine is the most commonly used $\alpha_{2}$-agonist in large animal internal medicine, and ruminants are more sensitive to this drug than are other species (Kastner, 2006; Rostami \& Vesal, 2012). Besides its effect as a potent muscular relaxant, it is used in epidural analgesia as it interacts with $\alpha_{2}$ receptors in descending pathways, at both the spinal and supraspinal levels (Guirro et al., 2011). Some of the possible undesirable effects of xylazine include respiratory depression, pulmonary edema, hypercapnia, transient arterial hypertension, hypotension, and bradycardia; these effects are dose dependent and most frequently observed after intravenous injections (Shah, Ding, \& $\mathrm{Hu}, 2014)$. Opioids are widely used in several species during the perianesthetic period and in severe pain management because of the analgesic effects of their interactions with $\mu$ and $\mathrm{K}$ receptors. Side effects related to the use of opioids include histamine release and consequent hypotension, bradycardia, and euphoria, all of which are associated with systemic administration. In contrast, when injected locally (e.g., epidurally), these side effects are rare (Moraes, Madureira, Bittencourt, Iwassa, \& Barbosa, 2018). Blood gas analysis is an important tool for the evaluation of the acid-base balance of organic fluids and the prognosis of some diseases (Soares, Leal, Mori, Sucupira, \& Ortolani, 2012). During anesthesia, many drugs induce cardiorespiratory depression, changing the acid-base balance (Ismail, Jawasreh, \& Al-Majali, 2010). This study aims to evaluate the cardiorespiratory effects of epidural ketamine, and its associations with morphine and xylazine, in ewes, and to correlate these effects with hemogasometric analysis to determine both the clinical and subclinical changes promoted by these drugs.

\section{Materials and Methods}

This study was approved by the Ethics Committee for Research Involving Animals of the Fluminense Federal University, protocol number 191. The experiment was conducted at the Goat and Sheep Experimental Research Unit located at the Farm School of the University, in the city of Cachoeiras de Macacu, Rio de Janeiro State,

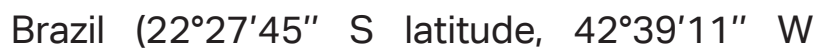
longitude, and $57 \mathrm{~m}$ altitude). Ten Santa Inês ewes aged 2 to 4 years with body weights of $50.7 \pm 5.4 \mathrm{~kg}$ (mean and standard deviation) and body condition scores from 2.75 to 3.5 , on a scale from 1 to 5 , were selected after clinical examination and laboratory analysis (hemogram, alanine aminotransferase, aspartate aminotransferase, urea, and creatinine dosages). The animals were kept in stalls and fed twice a day with hay and sheep balanced rations (18\% protein).

Food and water were withheld for 24 and $12 \mathrm{~h}$, respectively. The timing of all parameter assessments is described in the timeline in Figure 1. After the lumbosacral region was clipped, a basal assessment (time of baseline, TB) of the parameters heart rate $(H R)$, respiratory rate $(R R)$, ear temperature (T), and noninvasive blood pressure (NIBP) was performed and the values registered. HR and RR were assessed by auscultation with a stethoscope, $T$ was obtained with the aid of a digital thermometer, and systolic NIBP was assessed with a vascular flow Doppler cuff and manometer (Microem, Ribeirão Preto, Brazil), with the Doppler probe placed over the coccygeal artery and the cuff positioned around the tail proximally to the probe. 


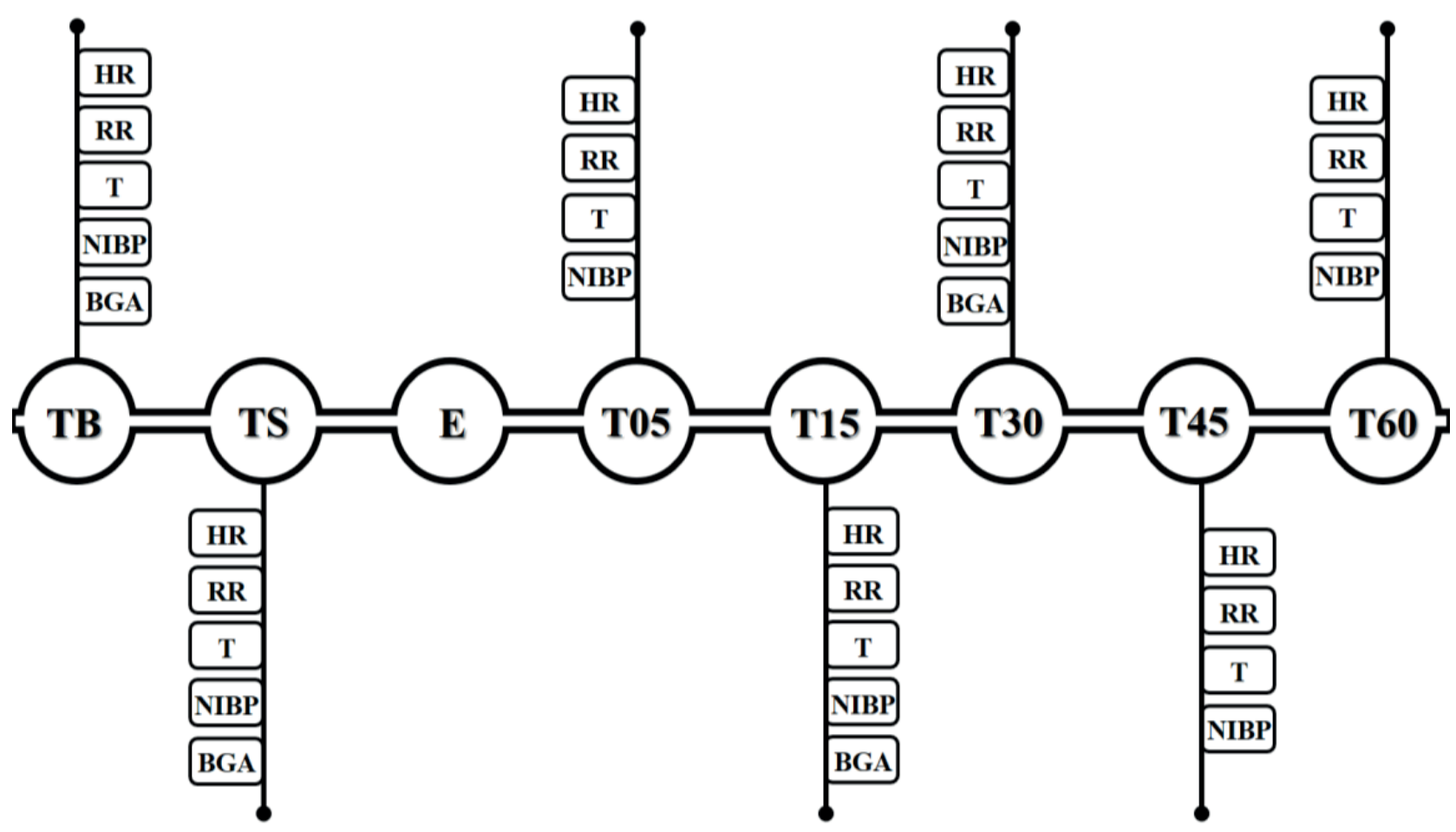

Figure 1. Graphic representation of evaluation times of physiological parameters and sample withdrawal for blood gas analysis. TB = time of baseline, before any drugs were administered; TS = time of sedation, 10 min after IV administration of acepromazine $\left(0.1 \mathrm{mg} \cdot \mathrm{kg}^{-1}\right)$ and diazepam $(0.2$ mg. $\mathrm{kg}^{-1}$ ); $\mathrm{E}=$ epidural; $\mathrm{T} 05$ to $\mathrm{T} 60$ = min after the epidural; $\mathrm{HR}=$ heart rate; $\mathrm{RR}=$ respiratory rate; $\mathrm{T}$ = ear temperature; NIBP = noninvasive blood pressure; BGA = blood gas analysis.

An arterial blood sample was collected from the caudal auricular artery using a 1-mL syringe and needle, and immediately processed in a portable gas analyzer (i-Stat, Abbott Laboratórios do Brasil, Rio de Janeiro, Brazil) with a CG8+ cartridge that provided the following parameters: $\mathrm{pH}$, oxygen partial pressure $\left(\mathrm{pO}_{2}\right)$, oxygen saturation, carbon dioxide partial pressure $\left(\mathrm{pCO}_{2}\right)$, total carbon dioxide, bicarbonate, base excess, hemoglobin, packed cell volume, sodium, potassium, ionized calcium, and glucose.

The ewes were sedated with acepromazine $\left(0.1 \mathrm{mg} \mathrm{kg}^{-1}\right.$ Acepran ${ }^{\bullet}$, Vetnil,
Louveira, Brazil) and diazepam $\left(0.2 \mathrm{mg} \mathrm{kg}^{-1}\right.$ Diazepam, Teuto, Anápolis, Brazil) intravenously and, 10 min after sedation, all the parameters were reassessed and registered (time of sedation, TS). The ewes were then placed in a sternal position on a procedure table and were aseptically prepared in the lumbosacral region with chlorhexidine (Rioquímica, Barueri, Brazil). A subcutaneous injection of $2 \mathrm{~mL}$ of lidocaine hydrochloride (Lidovet $^{\bullet} 2 \%$, Bravet, Rio de Janeiro, Brazil) was applied to desensitize the skin. An 18-gauge Tuohy needle (Perican', B. Braun, São Gonçalo, Brazil) was introduced at a $90^{\circ}$ angle to the skin and directed into the 
epidural space between the last lumbar and first sacral vertebra. The correct placement of the needle was confirmed using the hangingdrop technique and the loss of resistance to injection (Freitas et al., 2011). The injections were performed within $60 \mathrm{~s}$. The experimental treatments are shown in Table 1. All animals underwent each of the four treatments with a two-week interval between experiment days.

\section{Table 1}

Epidural treatments that ewes received in each group

\begin{tabular}{|c|c|c|c|}
\hline Group & Drug & Dose & $\begin{array}{l}\text { Number of } \\
\text { repetitions }\end{array}$ \\
\hline Ketamine Group $\left(\mathrm{G}_{\mathrm{K}}\right)$ & Ketamine $^{a}$ & $2.0 \mathrm{mg} \mathrm{kg}^{-1}$ & 10 \\
\hline $\begin{array}{l}\text { Ketamine and Morphine } \\
\text { Group }\left(G_{K M}\right)\end{array}$ & $\begin{array}{l}\text { Ketamine } \\
\text { Morphine }^{b}\end{array}$ & $\begin{array}{l}2.0 \mathrm{mg} \mathrm{kg}^{-1} \\
0.1 \mathrm{mg} \mathrm{kg}^{-1}\end{array}$ & 10 \\
\hline $\begin{array}{l}\text { Ketamine and Xylazine } \\
\text { Group }\left(G_{K X}\right)\end{array}$ & $\begin{array}{l}\text { Ketamine } \\
\text { Xylazine }^{c}\end{array}$ & $\begin{array}{l}2.0 \mathrm{mg} \mathrm{kg}^{-1} \\
0.05 \mathrm{mg} \mathrm{kg}^{-1}\end{array}$ & 10 \\
\hline Control Group $\left(\mathrm{G}_{\mathrm{S}}\right)$ & $\begin{array}{l}\text { Saline Solution } \\
\text { ( } \mathrm{NaCl} 0.9 \%)\end{array}$ & $\begin{array}{l}1 \mathrm{~mL} \text { per } 7.5 \mathrm{~kg} \\
\text { of body weight }\end{array}$ & 10 \\
\hline
\end{tabular}

The final volume was fixed in all groups, according to the formula used in $\mathrm{G}_{\mathrm{S}^{\prime}}$ and was completed with saline solution.

a Ketamina Agener ${ }^{\circledR}$ União Saúde Animal, União Química Farmacêutica Nacional, São Paulo, Brazil

b Dimorf॰ , Cristália Produtos Químicos Farmacêuticos LTDA., Itapira, Brazil

c Calmium 'Agener União Saúde Animal, União Química Farmacêutica Nacional, São Paulo, Brazil.

The parameters $H R$, RR, $T$, and NIBP were then assessed 05 (T05), 15 (T15), 30 (T30), 45 (T45), and 60 (T60) min after epidural injection, while blood gas analysis was repeated at T15 and T30. Ten minutes after epidural injection, the vaginal and uterine manipulations started, and the procedure lasted until $45 \mathrm{~min}$ after epidural injection. These manipulations consisted of clamping the cervix with the aid of Pozzi tweezers (Edlo, Porto Alegre, Brasil) and attempting to transpose it using a Hegar cervical dilator (Edlo, Porto Alegre, Brasil), a common procedure during artificial insemination or embryo transfer.

\section{Statistical analysis}

All data were analyzed with a mixed model, including the treatments and times as the main variables, as well as all their interactions. Variables are expressed as mean \pm SEM. They were subjected to two-way repeated measures ANOVA and compared using Tukey's tests. A value of $P<0.05$ was considered statistically significant. Statistical analyses were performed using SAS software (Statistical Analysis System Institute [SAS Institute], 2013). 


\section{Results and Discussion}

The physiological parameter data are shown in Table 2. When comparing the time of assessment, HR differed $(P=0.001)$ between baseline (68.30 $\pm 14.71 \mathrm{bpm}$, the lowest value) and T60 (117,90 $\pm 36,60 \mathrm{bpm}$, the highest value). Among the groups, $G_{K x}$ showed the lowest HR mean. When analyzing the groups $x$ time interactions, HR displayed an ascending pattern over time in all groups except in $G_{k x}$, in which, after an initial increase at TS, it decreased to baseline values and remained low until the end of the evaluation period, with a slight increase at T60. The baseline assessments (except for the blood gas analysis) were conducted in the sheepcote, while the subsequent assessments were carried out in the procedure room. This justifies the lower HR at TB than that at the subsequent evaluation times, since the animals were less stressed when manipulated in their usual surroundings. The high HR value at T60 was probably caused by manipulation stress, as it was the moment when the animals were removed from the procedure table. Studies on dairy cows that evaluated behavioral changes in animals under various milking conditions concluded that, when managed by unknown people and in unusual environments, the animals showed increased HRs, among other behavioral changes (Munksgaard, Depassillé, Rushen, Herskin, \& Kristensen, 2001). The low HR in the $G_{K x}$ group was expected, as xylazine may induce cardiac depression through a number of mechanisms, such as central nervous system sympathetic outflow reduction, the direct depression of the pacemaker and cardiac conduction, the inhibition of norepinephrine release from sympathetic terminals, and the increase of acetylcholine release by cardiac parasympathetic nerves (Shah et al., 2014). There was no change in blood pressure, which supports the idea that the effects on the cardiovascular system were minimal. This is possibly related to the route of administration and dose used, since most of the known effects are dose dependent. $\alpha_{2}$-Agonists tend to promote an initial pressure increase through peripheral vasoconstriction, mediated by stimulation of the $\alpha_{2}$ receptors of the vascular smooth musculature, followed by hypotension via baroreceptor reflex and sympathetic tone reduction. When administered intravenously, xylazine can lead to an initial $26 \%$ increase in mean arterial pressure, while intramuscular injections lead to an $18 \%$ increase (Shah et al., 2014). Epidural administration and the subsequent slow absorption into the systemic circulation, in addition to the low dose used, prevented these effects.

The RR showed a declining pattern from baseline to T60 in all groups except for in $G_{K X^{\prime}}$ which, unlike other groups $(P=0.001)$, showed a peak value at $\mathrm{T} 15$. The RR remained high in the $G_{k x}$ group, denoting a compensatory effect against the possible hypoxemia caused by xylazine. Although $\mathrm{pCO}_{2}$ did not increase at T15 as expected from the higher $\mathrm{RR}, \mathrm{pO}_{2}$ was low at this time point $(67.67 \pm 19.46 \mathrm{mmHg})$. These findings may indicate that hypercapnia occurred at some point between the epidural injection and T15, leading to compensatory tachypnea that was effective in reducing the $\mathrm{pCO}_{2}$ values. The increase could have escaped detection by the next blood gas analysis because $\mathrm{CO}_{2}$ is more soluble than $\mathrm{O}_{2}$. In ruminants, $\alpha_{2}$ adrenergic agonists may promote bronchoconstriction, reduce tidal volume, increase pulmonary vascular resistance, and cause pulmonary edema, 
leading to poor oxygenation with consequent hypoxemia (Singh et al., 2017). Tachypnea and irregular respiration were observed following the administration of low epidural doses of xylazine in small ruminants (Shah et al., 2014). In our study, when evaluating each treatment alone, all groups showed decreasing values of
RR over time, except for the $G_{K x}$ group. In this group, a significant increase was observed at T15, after which it followed the decreasing pattern, returning to baseline by T45. The hypoxemia and possible respiratory depression promoted by xylazine were transient and without complications. 


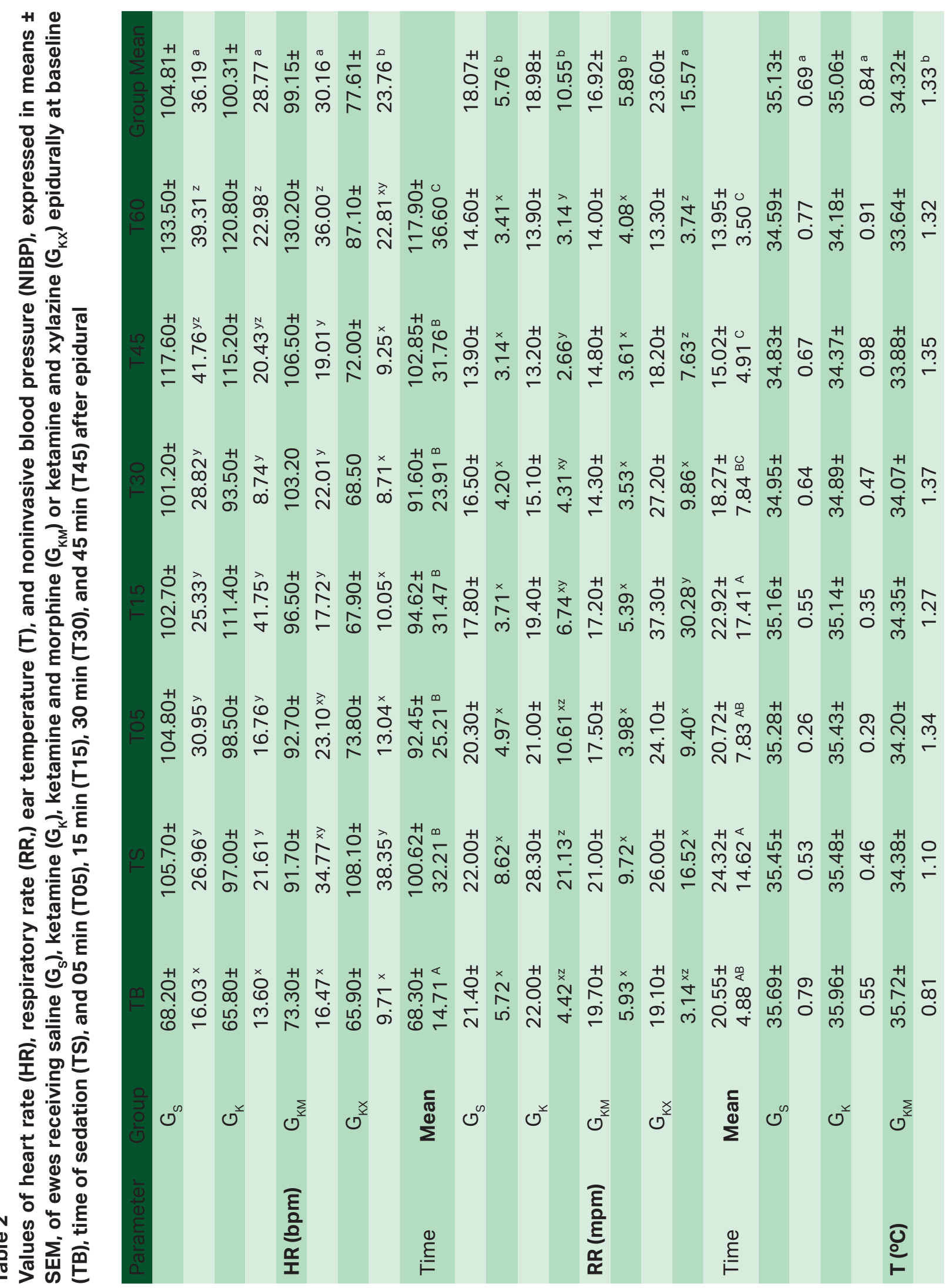




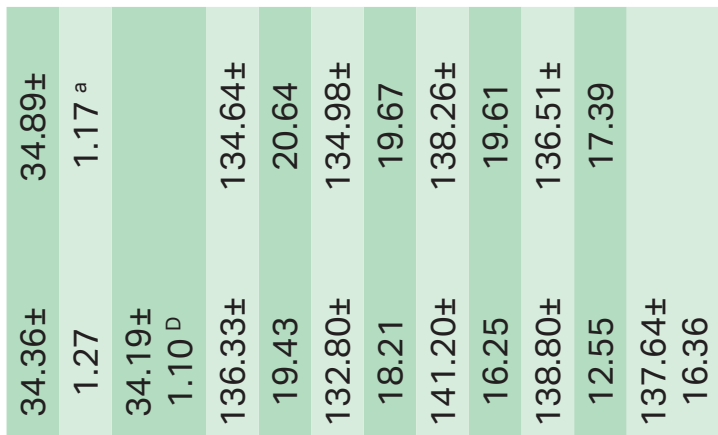

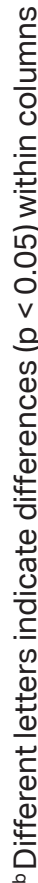

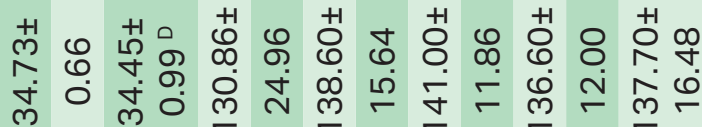

守 mे

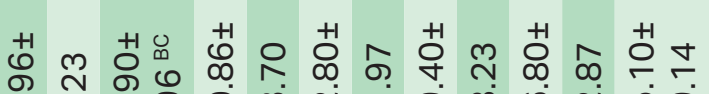
m

+

岗

ก)

ம்

ก

लூ

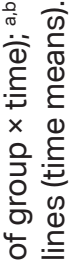

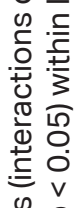

을

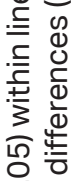

贶

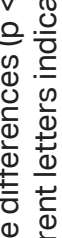

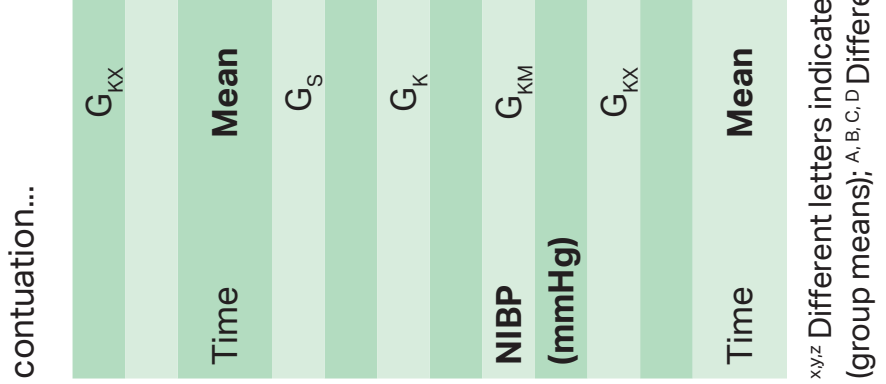


Temperature also varied in a descending pattern from TB to $T 60$ in all groups, and $G_{K M}$ had the lowest values $(P=0.001)$. A slight reduction was observed in the $G_{K M}$ group, which is not unexpected since morphine depresses the thermoregulatory center (Monteiro, Rodrigues, Assis, Campagnol, \& Quitzan, 2009) making the animal susceptible to ambient temperature changes. The average temperature in the procedure room was $23{ }^{\circ} \mathrm{C}$. Over time, all groups showed a slow and gradual reduction of $\mathrm{T}$, probably owing to the difference from the sheepcote temperature $\left(27^{\circ} \mathrm{C}\right)$ where the first assessment was performed.

The comparisons among groups and times of thebloodgas parameters $\mathrm{pO}_{2}, \mathrm{pCO}_{2^{\prime}}$ and $\mathrm{pH}$ are shown in Table 3. The $\mathrm{pCO}_{2}$ values were similar in all groups except for a slight decline at TS in group $G_{\mathrm{Kx}}$. The respiratory parameter $\mathrm{pO}_{2}$ in the blood gas analysis corresponds with the changes in RR, presenting lower values in $\mathrm{G}_{\mathrm{KX}}$. A low $\mathrm{pO}_{2}$ caused by reduced respiratory capacity promoted by xylazine is usually accompanied by a corresponding increase in $\mathrm{pCO}_{2}$, as shown in other studies (Ismail et al., 2010). In our study, this effect was not observed; only a mild imbalance of respiratory gases was seen in the $G_{K x}$ group. However, there was an increase in $\mathrm{pCO}_{2}$ at $\mathrm{T} 15$ and T30 in all groups. This finding is consistent with the reduction of RR usually observed in sedated animals, generating less alveolar gas exchange and thus increasing the concentration of $\mathrm{CO}_{2}$ in the bloodstream. Despite these differences in respiratory gases, the $\mathrm{pH}$ did not undergo any noteworthy variations, as shown in Table 3.

\section{Table 3}

Values of oxygen partial pressure $\left(\mathrm{pO}_{2}\right)$, carbon dioxide partial pressure $\left(\mathrm{pCO}_{2}\right)$ and hydrogen potential $(\mathrm{pH})$, expressed in means $\pm \mathrm{SEM}$, of ewes receiving saline $\left(\mathrm{G}_{\mathrm{S}}\right)$, ketamine $\left(\mathrm{G}_{\mathrm{K}}\right)$, ketamine and morphine $\left(G_{\mathrm{KM}}\right)$, or ketamine and xylazine $\left(\mathrm{G}_{\mathrm{KX}}\right)$ epidurally at baseline (TB), time of sedation (TS), and 15 min (T15) and $30 \mathrm{~min}$ (T30) after epidural

$\begin{array}{lcccccc}\text { Parameter } & \text { Group } & \text { TB } & \text { TS } & \text { T15 } & \text { T30 } & \text { Group Mean } \\ & \mathrm{G}_{\mathrm{S}} & 81.67 \pm 6.34 & 78.70 \pm 5.29 & 83.50 \pm 6.92 & 82.60 \pm 6.54 & 81.61 \pm 6.32^{\mathrm{a}} \\ \mathrm{pO}_{2} & \mathrm{G}_{\mathrm{K}} & 82.56 \pm 4.03 & 77.90 \pm 9.70 & 76.80 \pm 6.99 & 82.11 \pm 6.19 & 79.71 \pm 7.28^{\mathrm{ab}} \\ & \mathrm{G}_{\mathrm{KM}} & 85.40 \pm 5.25 & 81.60 \pm 7.83 & 80.70 \pm 11.09 & 83.56 \pm 6.56 & 82.79 \pm 7.91^{\mathrm{a}} \\ \text { Time } & \mathrm{G}_{\mathrm{KX}} & 80.88 \pm 6.77 & 81.56 \pm 7.50 & 67.67 \pm 19.46 & 75.22 \pm 11.68 & 76.23 \pm 12.77^{\mathrm{b}} \\ & \mathrm{Mean} & 82.64 \pm 5.63 & 79.52 \pm 7.88 & 77.40 \pm 12.75 & 81.02 \pm 8.28 & \\ \mathrm{pCO}_{2} & \mathrm{G}_{\mathrm{S}} & 35.32 \pm 3.05 & 35.88 \pm 2.02 & 37.58 \pm 1.18 & 39.15 \pm 1.57 & 37.02 \pm 2.47 \\ & \mathrm{G}_{\mathrm{K}} & 34.33 \pm 2.50 & 35.89 \pm 1.83 & 38.72 \pm 3.52 & 38.22 \pm 3.07 & 36.81 \pm 3.22 \\ & \mathrm{G}_{\mathrm{KM}} & 34.85 \pm 2.28 & 35.58 \pm 3.23 & 37.24 \pm 1.03 & 39.42 \pm 1.07 & 36.70 \pm 2.64 \\ \text { Time } & \mathrm{G}_{\mathrm{KX}} & 34.86 \pm 3.08 & 32.06 \pm 10.91 & 35.93 \pm 3.55 & 37.86 \pm 1.92 & 35.59 \pm 5.94 \\ & \mathrm{Mean} & 34.96 \pm 2.59^{\mathrm{A}} & 34.99 \pm 5.56^{\mathrm{A}} & 37.45 \pm 2.66^{\mathrm{B}} & 38.70 \pm 2.02^{\mathrm{B}} & \\ \mathrm{pH} & \mathrm{G}_{\mathrm{S}} & 7.48 \pm 0.02 & 7.47 \pm 0.04 & 7.47 \pm 0.03 & 7.47 \pm 0.03 & 7.47 \pm 0.02 \\ & \mathrm{G}_{\mathrm{K}} & 7.50 \pm 0.03 & 7.47 \pm 0.03 & 7.47 \pm 0.03 & 7.46 \pm 0.02 & 7.47 \pm 0.02 \\ \text { Time } & \mathrm{G}_{\mathrm{KM}} & 7.48 \pm 0.02 & 7.46 \pm 0.03 & 7.47 \pm 0.02 & 7.48 \pm 0.02 & 7.47 \pm 0.02 \\ & \mathrm{G}_{\mathrm{KX}} & 7.48 \pm 0.02 & 7.48 \pm 0.03 & 7.50 \pm 0.04 & 7.50 \pm 0.04 & 7.48 \pm 0.02\end{array}$

${ }^{a, b}$ Different letters indicate differences $(p<0.05)$ within columns (groups); ${ }^{A B}$ Different letters indicate differences $(p<$ 0.05) within lines (times). 
An interesting finding in our study was the significant reduction in packed cell volume and hemoglobin from TB to T30 in all groups, as shown in Table 4. The decrease was so significant that the values showed differences between all evaluation times, achieving a final value that was 34\% lower than that of the baseline packed cell volume. Considering that all groups showed the same pattern of decrease, this effect is most likely associated with the drugs administered during sedation, especially acepromazine. This drug induces relaxation of the splenic capsule and vasodilation, promoting the sequestration of red blood cells (Ambrósio et al., 2012). Nevertheless, a study on dogs showed no correlation between spleen volume and packed cell volume (Wilson, Evans, Carpenter, \& Mullineaux, 2004). This indicates that the reduction of packed cell volume in patients undergoing anesthetic protocols, during which vasodilation and relaxation of the splenic capsule are expected, is not only related to red cell sequestration in this viscera but also in the microcirculation of other organs such as the liver and kidneys, and even in the muscles or skin. Although it is a known phenomenon, the reduction in packed cell volume induced by sedative agents is poorly described, particularly in sheep. More studies are needed to determine whether there is a dose-response pattern, and to identify the beginning of the decline and the duration of this change.

\section{Table 4}

Packed cell volume and hemoglobin values (mean \pm SEM) of ewes at baseline (TB), after sedation (TS), and at $15(T 15)$ and $30(T 30)$ min after epidural with saline $\left(G_{S}\right)$, ketamine $\left(G_{K}\right)$, ketamine and morphine $\left(G_{K M}\right)$, and ketamine and xylazine $\left(G_{K X}\right)$

$\begin{array}{lcc} & \text { Packed cell volume (\%) } & \text { Hemoglobin (g/dL) } \\ \text { TB } & 28.24 \pm 3.17^{a} & 9.60 \pm 1.07^{a} \\ \text { TS } & 23.67 \pm 1.93^{\mathrm{b}} & 8.04 \pm 0.66^{\mathrm{b}} \\ \text { T15 } & 19.70 \pm 1.78^{\mathrm{c}} & 6.70 \pm 0.60^{\mathrm{c}} \\ \text { T30 } & 18.63 \pm 2.35^{\mathrm{d}} & 6.32 \pm 0.80^{\mathrm{d}}\end{array}$

a,b,c,d Different letters indicate differences $(P<0.05)$ within columns.

The glucose plasma concentration was higher $(P=0.001)$ in the $G_{\mathrm{Kx}}$ group $(94.84 \pm$ $21.11 \mathrm{mg} / \mathrm{dL})$ than that in the other groups $\left(\mathrm{G}_{\mathrm{S}}=\right.$ $80.53 \pm 15.45 \mathrm{mg} / \mathrm{dL} ; \mathrm{G}_{\mathrm{K}}=84.68 \pm 20.06 \mathrm{mg} / \mathrm{dL}$; $\mathrm{G}_{\mathrm{KM}}=79.00 \pm 11.27 \mathrm{mg} / \mathrm{dL}$ ). This was expected since xylazine directly inhibits insulin secretion by pancreatic beta cells and stimulates increased glucose production by the liver, promoting hyperglycemia (Shah et al., 2014). Although different from the other groups, the glycemia did not exceed the physiological limit for fasting animals.

\section{Conclusions}

All tested protocols were considered adequate for reproductive tract manipulation in this species. The cardiovascular and respiratory changes observed in this study 
were mild and did not compromise animal health. Epidural ketamine as a single agent is considered a more suitable protocol for the intended procedures because of its low cost.

\section{Acknowledgments}

This research was supported by Faperj, Universidade Federal Fluminense/ Proppi/Fopesq, EMBRAPA (Project 22.13.06.026.00.02) and CNPq (400785/20161). JFF and FZB are CNPq fellows.

\section{References}

Ambrósio, A. M., Ida, K. K., Souto, M. T. M. R., Silva, L. C. L. C., Soares, P. B., Ibiapina, B. T., Fantoni, D. T. (2012). Significant packed cell volume decrease in healthy horses during clinical anesthesia. Brazilian Journal of Veterinary Research and Animal Science, 49(2), 139-145. doi: 10.11606/issn.23183659

DeRossi, R., Módolo, T. J. C., Pagliosa, R. C., Jardim, P. H. A., Maciel, F. B., \& Macedo, G. G. (2012). Comparison of analgesic effects of caudal epidural $0.25 \%$ bupivacaine with bupivacaine plus morphine or bupivacaine plus ketamine for analgesia in conscious horses. Journal of Equine Veterinary Science, 32, 190-195. doi: 10.1111/j.14672995.2011.00689.x

Freitas, G. C., Carregaro, A. B., Gehrcke, M. I., De La Côrte, F. D., Lara, V., Pozzobon, R., \& Brass, K. E. (2011). Epidural analgesia with morphine or buprenorphine in ponies with lipopolysaccharide (LPS)-induced carpal synovitis. Canadian Journal of Veterinary Research, 75(2), 141-146. doi: 10.15361/ 2175-0106.2008v24n2p103-109
Guirro, E. C. B. P., Sobrinho, G. R., Ferreira, I. M. M., \& Valadão, C. A. A. (2011). Efeitos comportamental, clínico e analgésico promovidos pela injeção epidural preventiva de morfina, xilazina ou clonidina, em equinos. Ciência Rural, 41(10), 1790-1796. doi: 10.1590/S010384782011001000019

Habibian, S., Bigham, A. S., \& Aali, E. (2011). Comparison of lidocaine, tramadol, and lidocaine-tramadol for epidural analgesia in lambs. Research in Veterinary Science, 91(3), 434-438. doi: 10.1016/j.rvsc. 2010. 09.023

Ismail, Z. B. (2016). Epidural analgesia in sheep and goats: a review of recent literature. Bulletin UASVM Veterinary Medicine, 73(2), 197-202. doi: 10.15835/buasvmcnvm:12078

Ismail, Z. B., Jawasreh, K., \& Al-Majali, A. (2010). Effect of xylazine-ketamine-diazepam anesthesia on certain clinical and arterial blood gas parameters in sheep and goats. Comparative Clinical Pathology, 19(1), 1114. doi: 10.1007/s00580-009-0896-6

Kastner, S. B. R. (2006). Alpha2-agonists in sheep: a review. Veterinary Anaesthesia and Analgesia, 33, 79-96. doi: 10.1111/j. 1467-2995.2005.00243.x

Monteiro, E. R., Rodrigues, A. Jr., Assis, H. M. Q., Campagnol, D., Quitzan, J. G. (2009). Comparative study on the sedative effects of morphine, methadone, butorphanol or tramadol, in combination with acepromazine, in dogs. Veterunary Anaesthesia and Analgesia, 36, 25-33. doi:10.1111/j.1467-2995. 2008.00424.x

Moraes, V. J., Madureira, K. M., Bittencourt, R. F., Iwassa, C. H. D., \& Barbosa, V. F. (2018). Postoperative pain managementina sheep using continuous epidural morphine. Acta Scientiae Veterinariae, 46(1), 254. doi: $10.22456 / 1679-9216.85150$ 
Munksgaard, L., Depassillé, A. M., Rushen, J., Herskin, M. S., \& Kristensen, A. M. (2001). Dairy cows' fear of people: social learning, milk yield and behaviour at milking. Applied Animal Behaviour Science, 73(1), 15-26. doi: 10.1016/S0168-1591(01)00119-8

Rostami, M., \& Vesal, N. (2012). The effects of adding epinephrine or xylazine to lidocaine solution for lumbosacral epidural analgesia in fat-tailed sheep. Journal of South African Veterinary Association, 83(1), 1-7. doi: 10.4102/ jsava.v83i1.1

Shah, Z., Ding, M.-X., Hu, M.-L. (2014). Alfa2 antagonist in ruminant. Kafkas Üniversitesi Veteriner Fakültesi Dergisi, 20(4), 633639. doi: 10.9775/kvfd.2013.10541

Singh, P. M., Reid, K., Gaddam, R., Bhatia, M., Smith, S., Jacob, A., \& Chambers, P. (2017). Effect of choline chloride premedication on xylazine-induced hypoxaemia in sheep. Veterinary Anaesthesia and Analgesia, 44(5), 1149-1155. doi: 10.1016/j.vaa.2017. 01.002
Soares, P. C., Leal, M. L. R., Mori, C. S., Sucupira, M. C. A., \& Ortolani, E. L. (2012). Blood gas profile of copper-poisonedinsheeptreated with ammonium tetrathiomolybdate. Semina: Ciência Agrárias, 33(2), 731-740. doi: 10.5433/1679-0359.2012v33n2p731

Statistical Analysis System Institute Inc., 2013, Cary, NC, USA.

Wilson, D. V., Evans, A. T., Carpenter, R. E., \& Mullineaux, D. R. (2004). The effect of four anesthetic protocols on splenic size in dogs. Veterinary Anaesthesia and Analgesia, 31(2), 102-108. doi: 10.1111/ j.1467-2987.2004.00152.x 
